\title{
THE THEORY OF PRACTICE AND ACTION IN PAUL OF WORCZYN'S THOUGHT
}

\author{
Magdalena Plotka \\ Cardinal Stefan Wyszyński University, Warsaw
}

\section{Resumen}

El artículo presenta la teoría de la acción de Paul Worczyn. Se divide en tres partes: en la primera, se introduce la teoría de la acción como movimiento; la segunda parte se concentra en el problema de las causas de la acción; la tercera parte aclara el concepto del alma y sus poderes. El artículo termina llegando a concluir que las soluciones teóricas de Worczyn dentro de la teoría de la acción son coherentes desde una posición antropológica que acentúa la unidad del alma y sus poderes.

\section{Palabras clave}

Pablo de Worczyn; teoría de la acción; Ética; comentarios medievales a la Ética a Nicómaco; Filosofía medieval polaca

\begin{abstract}
The article presents Paul of Worczyn's theory of action. It is divided into three parts: in the first, Paul's theory of action as a motion is presented; the second concentrates on the problem of the causes of action; and the third clarifies the concept of the soul and its powers. The article concludes that Paul's theoretical solutions within the theory of action are consistent with his anthropological stance, which accentuates the unity of the soul and its powers.
\end{abstract}

\section{Keywords}

Paul of Worczyn; Theory of action; Ethics; Medieval Commentaries on Nicomachean Ethics; Polish Medieval Philosophy 
The academic milieu of the University of Cracow in Poland was created only in summer 1400, when the King of Poland, Władysław Jagiełło, renewed the Cracow Academy (established in 1364) and founded the faculty of theology. According to the king's words that were found in documents related to the founding of the university, Cracow University would become "a pearl of powerful learning ${ }^{1}$ in Central Europe, and its professors would create the intellectual elite of the country. ${ }^{2}$

Jagiełło's intention was that the newly founded university would educate the class of professionals (lawyers in particular) who would take care of Poland's internal and external political interests. ${ }^{3}$ In order to meet Jagiełło’s requirements, emphasis was put on practical disciplines at Cracow University: law, political philosophy, and ethics. From the inaugural speech delivered at the opening ceremony by Stanisław of Skarbimierz 4 (who was the first rector of the university), one can learn about the ideological program of the university: the faculty of theology, according to Stanisław,

${ }^{1}$ Knoll, P. W., A Pearl of Powerful Learning. The University of Cracow in the Fifteenth Century, Leiden/Boston, Brill, 2016, pp.10-41; see also Stopka, K., «The Jagiellonian Foundation of Cracow University», Quaestiones medii aevi novae, 8 (2003), pp. 49-66.

${ }^{2}$ Knoll, A Pearl of Powerful Learning, op. cit., p. 11: «From this act and those to follow in the next days, the school in Cracow eventually come to honor Jagiełło as its greatest benefactor, and today it is known as Jagiellonian University (Universitas Jagellonica, Uniwersytet Jagielloński)».

${ }^{3}$ Ibid., pp. 220-221: «According to Jagiełło, the university intended to play an important part in the national life of Poland. As Knoll reports, 'the role it played included such disparate elements as the reform of the Polish church, support for state policy against such enemies as the Teutonic Order, upholding the union with Lithuania, engaging in the problems posed by the Hussite movement in Bohemia, participation in the great issues of the larger church as reflected in the conciliar movement, particularly the Council of Basil, and the emergence of national identity as reflected in language, administration, education, and even patriotism'». See also Ożóg, K., «Die Krakauer Universität und ihre Teilnahme am öffentlichen Leben des jagiellonischen Königreiches», in W. Falkowski and S. Weinfurter (eds.), Ritualisierung Willensbildung. Polen und Deutschland im hohen und späten Mittelalter, Wiesbaden, Harrassowitz, 2010, pp. 163-181.

${ }^{4}$ Stanisław of Skarbimierz (1365-1413) was a theologian, canonist, philosopher and rector of Cracow University. He started his career in Prague. He completed a master's degree in arts in 1385, and in 1389 he started studying law. He came back to Cracow in 1396 and got involved in the renewal of the University of Cracow. He applied his legal knowledge during the Great War with the Teutonic state (1409-1411). He wrote an influential sermon on just war, which has become part of the output of the so-called Polish school of international law. See Wielgus S., Polska średniowieczna doktryna ius gentium, Lublin, Redakcja Wydawnictw KUL, 1996. For the speeches and sermons of Stanisław of Skarbimierz, see ms BJ 191 and BJ 723 (in Jagiellonian Library in Cracow, Poland). For editions and translations of Stanisław's speeches, see Stanisław ze Skarbimierza, Sermones, B. Chmielowska (ed.), Warszawa, Wydawnictwo Akademii Teologii Katolickiej, 1979; for Polish translations of Stanisław's speeches, see Stanisław ze Skarbimierza, Pochwała Uniwersytetu na nowo ufundowanego, in J. Domański (ed.), 700 lat myśli polskiej. Filozofia i myśl społeczna XIII-XV wieku, Warszawa, Państwowe Wydawnictwo Naukowe, 1978; for a detailed analysis of the inaugural speech of Stanisław, see Płotka, M., «Praktyczny wymiar nauki», in Filozofia jako praktyka. Myśl krakowskiego praktycyzmu w XV i XVI wieku, Warszawa, Wydawnictwo UKSW, 2016, pp. 38-46. 
would deal with matters of the soul; the faculty of medicine had the «responsibility to train good physicians, thereby ensuring that men would live long and fruitful lives». ${ }^{5}$ Also, when Stanisław addressed the community on the importance of law, especially canon law, he stressed the importance of also teaching practical and theoretical philosophy at the faculty of arts. As P. W. Knoll notes, in Stanisław's view

canon law was an all-encompassing discipline: it treated questions derived from the trivium and the quadrivium, as well as from practical philosophy, medicine, and theology. ${ }^{6}$

Although one might be surprised by Stanisław's exaggerated admiration for his own discipline, «it shows a pragmatic cast which accords well with the ambition of Jagiełło to have the university serve society». ${ }^{7}$ Therefore, due to this tradition, the majority of medieval scholars (especially those working in the faculty of arts in 14011452) were primarily interested in practical rather than theoretical philosophy. As a consequence, practical philosophical disciplines (ethics, political philosophy, economics and social studies, etc.) came to the forefront of philosophical consideration.

A lot has been already written on the pragmatic orientation of medieval education in Cracow. ${ }^{8}$ Polish researchers have studied various traces of practicality in Cracow manuscript sources (most of the sources are still unedited and are mostly old prints or manuscripts), which show pragmatic trends in philosophy in particular. 15th-century pragmatism in Cracow is usually defined as philosophical reflection whose purpose is activity (operatio) and work (opus). Therefore, the pragmatism of Cracow scholars puts more emphasis on the practical fields of philosophy and focuses on practice and action, but it neglects theoretical philosophical disciplines like metaphysics or logic.

One of the most important and prominent representatives of Cracow's practical trend in philosophy was Paul of Worczyn (1383-1430). He was a representative of the popular belief that knowledge is important insofar as it results in action; he claimed,

${ }^{5}$ Knoll, A Pearl of Powerful Learning, op. cit., p. 37.

${ }^{6}$ Ibid.

${ }^{7}$ Ibid.

8 See Ibid., op. cit., p. 220-286; Korolec, J.B., «Praktycyzm piętnastowiecznej etyki krakowskiej», in J.B. Korolec, Wolność, cnota, praxis, Warszawa, Wydawnictwo IFIS PAN, 2006, pp. 187-207; On practicality of Polish medieval philosophy, see also Płotka, Filozofia jako praktyka, op. cit., pp.10-32; Domański, J., Scholastyczne i humanistyczne pojęcie filozofii, Kęty, Wydawnictwo Antyk, 2005, p. 137; Korolec, J.B., Filozofia moralna Jana Burydana. Paryski wzór krakowskich dysput z zakresu Etyki w pierwszej połowie XV wieku, Wrocław-Kraków-Warszawa-Gdańsk, Wydawnictwo Polskiej Akademii Nauk, 1973, p. 7; Czerkawski, J., Humanizm i scholastyka. Studia z dziejów kultury filozoficznej w Polsce w XVI i XVII wieku, Lublin, Redakcja Wydawnictw KUL, 1992, p. 86; Swieżawski, S., U źródeł etyki nowożytnej. Filozofia moralna w Europie $w$ XV wieku, Kraków, Społeczny Instytut Wydawniczy Znak, 1987, p. 45; Włodek, Z., «Krakowski komentarz z XV wieku do Sentencji Piotra Lombarda. W poszukiwaniu tendencji doktrynalnych na wydziale teologicznym Uniwersytetu Krakowskiego w XV wieku», Studia Mediewistyczne, 9 (1968), p. 250. 
for example, that wisdom has value in so far as it results in moral virtues. ${ }^{9}$ He started his career at the University of Prague, where in 1403 he completed his baccalaureate at the faculty of arts. Next, he moved to Leipzig and graduated as a Master of Arts in 1409. He lectured in Leipzig until 1414 and then moved to Cracow, where he worked at the faculty of arts and simultaneously started his theology studies. In 1426, he gained the title of Professor of Theology.

Paul mainly wrote commentaries on Aristotle. His commentary on the De anima was his first work (finished in 1417). ${ }^{10} \mathrm{He}$ also commented on Parva naturalia, Meteora and De generatione et corruptione, but, a quaestio-form commentary on Nicomachean Ethics is his most important work (finished in 1426). This commentary is preserved in three manuscript copies at Jagiellonian Library in Cracow (sign. BJ 720, BJ 741 and BJ 2000). ${ }^{11}$ Paul was mostly inspired by the philosophy of John Buridan, Marsilius of Inghen, Gerald Odonis and Thomas Aquinas, and these inspirations can easily be found in his commentaries on De anima and Nicomachean Ethics. ${ }^{12}$ He was mainly interested in ethics and economic and philosophical anthropology. None of his works have yet been edited critically.

The intellectual atmosphere of Cracow University helps to explain the fact that Paul concentrated so much on ethical and practical issues. In his commentary on Nicomachean Ethics, he considered not only a number of metaethical or moral philosophical issues (numerous issues regarding the border between law and ethics deserve special attention), ${ }^{13}$ but he also tackled the issue of the foundation of all kinds of practice, namely the overall nature of action. ${ }^{14}$

P. W. Knoll identifies Paul as «the most important Cracovian commentator upon Aristotle's Ethics of the century ${ }^{15}$ and notices that the importance of practical as

${ }^{9}$ Paulus de Worczyn, Quaestiones super libris Ethicae Nicomacheae Aristotelis, op. cit., f. 192rb.

10 Paulus de Worczyn, Quaestiones super tres libros De anima, J. Rebeta (ed.), WrocławWarszawa-Kraków, Wydawnictwo PAN, 1969.

${ }^{11}$ For the most concise study of Paul of Worczyn's commentary on Nicomachean Ethics, see Rebeta, J., Komentarz Pawła z Worczyna do Etyki nikomachejskiej Arystotelesa z 1424 roku. Zarys problematyki filozoficzno-społecznej, Wrocław - Warszawa, Wydawnictwo PAN, 1970, pp. 93-100.

${ }^{12}$ Judycka, J., «Paweł z Worczyna», in A. Maryniarczyk (ed.), Encyklopedia filozofii polskiej, vol. 2, Lublin, Polskie Towarzystwo Tomasza z Akwinu, 2011, pp. 314-316; On Paul's of Worczyn sources, see Knoll, A Pearl of Powerful Learning, op. cit., pp. 340-342; Korolec, J., «Le comantaire de Jean Buridan sur l'Éthique à Nicomaque et l'université de Cracovie dans la première moitié du XVe siècle», Organon, 10 (1974), pp. 187-208.

${ }^{13}$ See Olszewski, M., «Secundum probata czy secundum veritatem? Uwagi na marginesie lektury komentarza do Etyki nikomachejskiej Pawła z Worczyna (księga V, kwestia 40)», Przegląd Tomistyczny, 21 (2015), pp. 347-365.

${ }^{14}$ Paulus de Worczyn, Quaestiones super libris Ethicae Nicomacheae Aristotelis, op. cit., f. 146rb; see Płotka, M., «Podstawy aktywistycznej filozofii człowieka w ujęciu Pawła z Worczyna», Studia Antyczne i Mediewistyczne, 10 [45] (2012), pp. 275-287.

${ }^{15}$ Knoll, A Pearl of Powerful Learning, op. cit, p. 323. 
opposed to speculative or abstract study is central to Paul's concerns. Therefore, the aim of my article is to present the basic concepts and themes of Paul of Worczyn's theory of practice, which were founded in his ontology of action, investigation of the soul and metaphysics of a man.

I mainly refer to commentary BJ 720 and the simple edition of De anima ${ }^{16}$ as these two works seem to contain a full systematic lecture on Paul's ethics and anthropology. Also, in order to show the common consent of Cracow academia, I refer occasionally to other Cracow masters who investigated related philosophical issues.

The article is divided into three parts. First, I will provide an overview of Paul's conception of action as a motion. As I will show, the definition of action advanced by Paul (as well as other Cracow philosophers) is broad enough to contain such different actions as intellectual cognition or chopping with an axe. The context of the formulation of this definition was natural philosophy, which was popular in Cracow. The consequence of adopting this definition was Paul's reflections on internal mental acts as actions (immanent action). In the second part, I will discuss the causes of action. I will present Paul's consideration on the conditions that must be met by the principle that could be the cause of action. The sources of Paul's opinion are intellectual (Thomas Aquinas) and voluntary (Gerald Odonis), but I will argue that Paul takes John Buridan's view. In the third part, I will focus on Paul's theory of the soul and its powers. Precisely, I will show that Paul's conception of action is based on the thesis of the unity of the soul and its powers.

\section{Action as motion}

In his commentaries on The Soul and Nicomachean Ethics, Paul of Worczyn laid the foundation for his theory of action by investigating the nature of action, the different types of actions, the criteria used to differentiate them, as well as the causes and principles of action. Like other Cracow philosophers such as Benedict Hesse, ${ }^{17}$ Andrzej

\footnotetext{
${ }^{16}$ Paulus de Worczyn, Quaestiones super tres libros De anima, op. cit.

${ }^{17}$ Benedict Hesse (1389-1456) started his studies at the faculty of arts in Cracow in 1407; he became a master of arts in 1415 and then completed a doctorate in theology in 1431. He was six times rector of Cracow University. He commented on Aristotle and debated with the Hussites. He was mainly interested in politics and natural philosophy. He was influenced by the thought of John Buridan, Marsylius of Inghen and Lawrence of Lindores. As a Buridanist, Benedict popularized the theory of impetus in Cracow. Benedict Hesse, Benedicti Hesse Quaestiones disputatae super tres libros De anima Aristotelis (Liber II et III), W. Bajor (ed.), Lublin, Wydawnictwo KUL, 2011; Benedictus Hesse, Quaestiones super octo libros Physicorum Aristotelis, S. Wielgus (ed.), Wrocław, Polska Akademia Nauk, Instytut Filozofii i Socjologii, 1984; Markowski, M., Teoria impetu w polskich średniowiecznych komentarzach do Fizyki Arystotelesa, Wrocław-Warszawa-Kraków, Wydawnictwo PAN, 1968.
} 
Wężyk ${ }^{18}$ or the anonymous author of Jagiellonian manuscript BJ 513 - to name but a few - Paul suggests a general account of action as motion. ${ }^{19}$ Each action is treated as a type of motion regardless of whether it concerns sensory perception, eating, an act of will or contemplation as an intellectual activity. Unlike Aristotle, Paul does not investigate action as an activity that is actualized by its purpose: he considers it from the perspective of its causes and principles. Indeed, it is the problem of the causes and principles of action that provides the focal point of Paul's reflections in the area of practical philosophy. The theory of motion is the context of his discussions on the theory of action. Let us note that the emphasis on motion in research on anthropological issues (study of man, study of the soul, etc.) resulted from some methodological assumptions that were characteristic of the entire Cracow milieu: natural philosophy was the appropriate context for metaphysical and anthropological considerations.

Following the Aristotelian tradition, ${ }^{20}$ Paul and some other Cracow philosophers defined action in the most general terms as a type of motion, regardless of the context, the field of activity, or the espoused doctrine. Let us look at some of the concepts of motion in order to clarify its usage and applications in philosophical disciplines at Cracow University.

First of all, it should be said that physics (and all natural philosophy) in Cracow was greatly influenced by the writings of John Buridan and his students (Nicholas Oresme, Albert of Saxony and Marsilius Inghen). Jagiellonian Library has 46 manuscripts containing 60 works by Buridan or his students. ${ }^{21}$ One of the main issues considered by Cracow academics who worked in the field of natural philosophy was motion, through which the subject of natural philosophy (ens mobile and corpus mobile) was established. ${ }^{22}$ For example, John Toszka believed that natural philosophy mainly considers a mobile being, which is its most important subject, while metaphysics deals with immobile

${ }^{18}$ Andrzej Wężyk (1377-1430) studied in Prague, where he gained his baccalaureate in 1397. He became a master of arts in Cracow in 1403. He is an author of a large commentary on Aristotle's Physics. He died probably in Lublin. Grzesik, T., «Andrew Wanszyk O.P. (A. Wężyk) alias Magister Serpens and Work Attributed to His Authorship», Vivarium, 33/2 (1995), pp. 235-241; Disputationes 'Physicorum' dictae Magistri Serpentis 'Exercitium': (editio critica), T. Grzesik (ed.), Warsaw, Institute for the History of Science, 2016.

${ }^{19}$ Paulus de Worczyn, Quaestiones super libris Ethicae Nicomacheae Aristotelis, op. cit., f. 194ra: «quaelibet operatio dicitur motus».

${ }^{20}$ David Charles points out three elements of motion in Aristotle: the object which is moved, the medium in which the movement occurs and the time at which it occurs. Charles, D., Aristotle's Philosophy of Action, New York, Cornell University Press, 1984, p. 6.; See Aristotle, Physics 227b21228a2.

${ }^{21}$ Markowski, M., Wpływ burydanizmu na Uniwersytet Krakowski w pierwszej połowie XV wieku, in Z. Kuksewicz (ed.), Z dziejów filozofii na Uniwersytecie Krakowskim w XV wieku, Wrocław-WarszawaKraków, 1965, p. 120.

${ }^{22}$ Markowski, M., Filozofia przyrody $w$ drugiej połowie XV wieku, Wrocław-Warszawa-KrakówGdańsk-Łódź, Wydawnictwo IFiS PAN, 1983, p. 92. 
beings. ${ }^{23}$ Philosophers of the first half of the $15^{\text {th }}$ century, such as Paul of Worczyn, disregarded the difference between ens and corpus and took the position that ens mobile is the subject of natural philosophy. Moreover, when answering the question of motion as a property of being, they indicated a broad understanding of the term ens, since this term also included form. For example, the anonymous author of manuscript BJ 1946 proposed that a mobile being has to be defined as variable in terms of form (ens mobile ad formam).$^{24}$ Similarly, Paul of Worczyn took the position that a mobile being should be understood in relation to the form of a complex imperfect body. Thus, he adopted the view of Albert of Saxony. ${ }^{25}$

Paul deals with the issue of motion in his commentaries on Aristotle. In a question in the commentary on Nicomachean Ethics, Paul also tries to establish the difference between proper motion (motus proprie) and becoming (generatio). On Paul's account, a generatio is a substantial change because it occurs between two contradictory states (not-A and A), or between a «privative» and a «positive» term, as Paul puts it. Motion, by contrast, is a change in an accidental category as it occurs between two contrary states (A and B), which are "positive terms», in Paul's words. ${ }^{26}$ For instance, the substantial change that occurs when water turns into steam is between the water not being in the form of steam (not-A) and the water being in the form of steam (A). The accidental change of water being heated from 20 to 30 degrees Celsius is its moving from being at 20 degrees (A) to being at 30 degrees (B).

Paul's definition of motion (as the relation between positive terms) is so general that he can easily use it to account for any action. For example, in his commentary on Nicomachean Ethics, he says that since no action can be an experience, it must be a type of motion. ${ }^{27}$ His definition is also in line with the Aristotelian theory of potentiality and actuality; this is why, in his commentary on On the Soul, he suggests differentiating motion as an «act of being» (claiming that this definition, which originates from Aristotle's Physics, is correct) and as random change. ${ }^{28}$ Reflecting upon motion from a proper, i.e. metaphysical, perspective as an act of being, Paul identifies as many as four types of acts, one of which he describes as an act which is accounted for as the experience or change of the agent himself, and motion is thus understood when it is

${ }^{23}$ Ibid., 93.

${ }^{24}$ Paul of Worczyn, Quaestiones super I - IV libros Meteorum Aristotelis, book I, ms BJ 2073, f. 137 r.

${ }^{25}$ Ibid., f. 124v: «Queritur, quid sit subiectum presentis scientiae. Communiter dicitur, quod hoc complexum, secundum Albertum, ens mobile contractum ad formam mixti imperfecti».

${ }^{26}$ Paulus de Worczyn, Quaestiones super libris Ethicae Nicomacheae, op. cit., 170va-vb: «Respondetur, quod illa, quia motus proprie $|170 \mathrm{vb}|$ dictus semper est inter terminos positivos, generatio autem semper habet terminum privativum et positivum».

${ }^{27}$ Ibid., f. 172va: «Nulla operatio est passio proprie dicta».

${ }^{28}$ Ibid., f. 170rb: «Sciendum. Motus sumitur multipliciter, sed quantum ad praesens dupliciter sumitur: Uno modo proprie et secundum quod difinitur III Physicorum: [est actus entis] etc. Alio modo, sumitur communiter pro qualibet transmutatione etiam instantanea». 
described as an act and action. ${ }^{29}$ So, Paul gives here a broad account of action-motion as an unfolding change. What is noteworthy in Paul's definition is his conclusion that action as change may take place in the agent himself. He offers an example of pleasure (delectatio) in order to explain it better. He does not want to consider pleasure as a kind of passive experience (passio) and argues that pleasure is an action. His argument is as follows: if an agent performed action A, which resulted in pleasure B, the pleasure gains the status of motion-action because, on the one hand, it is a consequence of action (A), but on the other hand it can itself be described as a relation between action and the achievement of a new quality (affect) of the agent. ${ }^{30}$ Let us try to explain this with an example: if I tidy up a messy room (I perform action $A$ ) and the purpose is the tidiness of the room (B), then the relationship between A and B (between tidying up and tidiness, i.e. my action and its purpose) is the pleasure I take from achieving the intended purpose. Since the relationship between A and B is proper motion, pleasure is also a kind of motion. Obviously, one can argue with Paul's understanding of pleasure itself, but the point is that mental acts (such as pleasure) are considered by Paul to be motion and action.

The definition of action that underlies Paul's discussion of pleasure as motion suggests a broad understanding of action as a concept that includes external and internal acts in equal measure. In fact, Paul clarifies his conception of internal and external actions in the commentary on Nicomachean Ethics. He writes there that

action is twofold. First, there is action, such as burning or cutting, that comes from the agent and is [aimed] at external matter. This type of action is not the perfection of the agent but of the experiencing subject. Another [type of] action remains within the agent himself, just like sensory perception or intellection. ${ }^{31}$

Hence, Paul understood the category of action to comprise both actions directed towards the world as well as internal acts because he adopted a general conception of action as motion. ${ }^{32}$

${ }^{29}$ Paulus de Worczyn, Quaestiones super tres libros De anima, op. cit., p. 11: « Tertio modo actus sumitur pro passione vel mutatione ipsius operantis, et sic capitur in definitione motus, cum dicitur: motus est actus et operatio».

${ }^{30}$ Ibid., 188vb-189va: «Delectatio non est passio, quia nulla operatio est passio. Sed delectatio est operatio. [...] delectatio est effectus $|189 \mathrm{va}|$ consequens operationem naturalem non impeditam».

${ }^{31}$ Paulus de Worczyn, Quaestiones super libris Ethicae Nicomacheae, op. cit., f. 191va.: «De tertio, sicut habetur IX Metaphysicae, duplex est actio. Una, quae procedit ab operante in materiam exteriorem, sicut urere, secare etc. Et talis actio non est perfectio agentis, sed magis patientis. Alia vocatur actio manens in ipso agente, sicut sentire, intelligere».

${ }^{32}$ Such an account of action is also present in the writings of other Cracow scholars. Let me mention two examples of understanding motion in Cracow to see that Paul's concept shows a common tendency: Andrzej Wężyk underlines the successive and gradual nature of actionmotion. In his commentary on Physics, he claims that «any action that does not occur immediately 
Although Cracow philosophers sometimes had different opinions, when it came to specific aspects of action (whether it is a change, whether it occurs in the agent, whether it defines the totality of nature, etc.) and approached them from various perspectives (metaphysical, physical and cosmologic), they were in agreement that action is a type of motion. As we shall see, this account had far-reaching consequences: it focused the attention of the Cracow scholars on the possibility of considering actionmotion in terms of cause-and-effect relations; more importantly, it opened the door to studying human actions by means of the tools of natural philosophy.

\section{The causes of action}

Paul of Worczyn continues his reflections on action in his commentary on Nicomachean Ethics. He suggests two meanings of action and then reflects upon action in terms of its causes. On the one hand, causes of motion are divided into external and internal in relation to a moving subject: in as much as a hand throws a stone, it represents the external cause of the stone's motion, whereas anger is the internal cause of (the action) initiating an attack. On the other hand, they are divided based on their relation to motion: an object may be movable or immovable as well as motive and nonmotive..$^{33}$ For example, a billiard ball that imparts motion to another ball is a cause that is both motive (because it made the other ball move) and moved (because it had been moved by the billiard player). Given that only an active principle is able to make something else move, motion can be caused solely by a motive factor. Paul goes on to say that, in the case of human actions, causes of motion are exclusively internal (a stone moves due to an external principle, but a man can act of his own volition and does not need any external factor).

Searching for the principium of action, Paul points out two of its properties: first, it must be a motive (active) principle; second, it must be internal. In other words, for a factor to be a principle of action, it must be able to move something else and be located in human nature itself. It cannot be external in relation to the agent. Situating the cause of motion inside the agent was so important for Paul that he decided to part from the Aristotelian praxis-poiesis division. ${ }^{34}$ For Aristotle, as we know, the domain of praxis

is motion». See Andrzej Wężyk, Disputationes 'Physicorum' dictae Magistri Serpentis, op. cit., p. 333: «omnis actio, quae non fit in instanti, illa est motus». Also, the anonymous author of manuscript BJ 513 also follows in the Neoplatonic tradition and defines action as the most fundamental property of all of nature: « natura enim est primum movendi et quiescendi eius in quo est, [...] eiusdem conditioris et auctoris operatio in hoc quod dicitur: [facit]; facit enim motum ab aeterno». Anonymous, ms BJ 513; quoted in Czartoryski, P., Wczesna recepcja Polityki Arystotelesa na Uniwersytecie Krakowskim, Wrocław - Warszawa - Kraków, Wydawnictwo PAN, 1963, p. 84.

${ }^{33}$ Paulus de Worczyn, Quaestiones super libris Ethicae Nicomacheae, op. cit., f. 146rb.

${ }^{34}$ Referring to the common opinion, according to which action is a subject of practical science as such, and arguing for the practical nature of the study of soul and ethics, Paul could demonstrate that action is the subject of both psychology and ethics. However, he raises 
included actions whose consequences remained in the agent, while poiesis comprised actions whose results were external to the agent. Hence, according to Aristotle, the difference between praxis and poiesis was defined by the internality or externality of their consequences for agents. For instance, by doing just acts we acquire a permanent disposition in the form of the virtue of justice, which is something internal for the agent, whilst the consequence of building a house is the house itself, which remains outside the agent.

Cracow scholars were not comfortable with the Aristotelian division into praxis and poiesis, which coincided with the division into internal and external actions. Depending on whether action encompassed internal and external acts or only external ones, the definition of action was either broad or narrow. This problem was analysed, among others, by the anonymous author of Utrum Deus gloriosus, ${ }^{35}$ who put the Aristotelian theory in the context of his own theological reflections, and John of Głogów. ${ }^{36}$

terminological and methodological objections to this opinion. First of all, in his opinion it is necessary to define the very concept of action, which is crucial to understanding the category of practice; thus, this is all crucial for resolving whether a given science is practical or theoretical. Secondly, he also tends to reflect upon the principle according to which the subject of science determines the character of science itself. For Paul, this rule is too general and requires additional clarification; moreover, he says it is logically erroneous because the fact that action is an object of science does not yet indicate that science is practical because the object is not the only criterion for qualifying a discipline as practical or theoretical. In his commentary on De anima, Paul writes: «the sentence 'action is the purpose of this science' does not follow from the sentence 'so it is a practical science', but it should be argued that 'the external action is the purpose of this science'; therefore, it does not concern any action» (Paulus de Worczyn, Quaestiones super tres libros De anima, op. cit., p. 40). It already follows from Paul's initial reflections that he does not share the Aristotelian view of the division of «praxis» and "poiesis»; for Aristotle, praxis is limited only to actions that produce effects in the agent (that is why ethics, which includes the acquisition of virtues, is a practical science), whereas poiesis is related to a productive activity which results in artifacts. See Aristotle, Nicomachean Ethics, 1140b 6-7; 1094a4; 1176b 2-10.

${ }^{35}$ The anonymous commentary on Sentences Utrum Deus Gloriosus came to Cracow from Prague and was used for the entire $15^{\text {th }}$ century. Many Cracow scholars based their own commentaries on Sentences. Although Utrum Deus Gloriosus is a theological work, it serves as an important point of reference to determine the practical tendency in theology in Cracow. As P.W. Knoll reports, «Krzysztof Michalski first called attention to Utrum Deus Gloriosus as an important text for the history of fifteenth-century Polish thought. He at first identified it as identical to the Prague lectura communis, and he consequently argued that both texts came from a single author. Andrzej Półtawski analyzed both works, however, and showed they are separate and independent, do not form a whole, and undoubtedly come from two different authors». See Knoll, A Pearl of Powerful Learning, op. cit., p. 427n11, at pp. 473-483.; Michalski, K., «Tekst, osobistość, szkoła i prąd w filozofji średniowiecznej», Pamiętnik IV Wszechnego Zjazdu Historyków Polskich w Poznaniu, Poznań 1925, pp. 1-13; Kałuża, Z., Un Manuel de théologie en usage à l'Université de Cracovie: Le commentaire des Sentences dit Utrum Deus Gloriosus, in L'Église et le people chrétien dans le pays de l'Europe du Centreest du Nord (XIV-XVe siècles), Rome, École Française de Rome, 1990, pp. 107-124.

${ }^{36}$ John of Głogów (1445-1511) was a representative of the younger generation of Cracow scholars in the 15th century. He started his studies at the faculty of arts in Cracow in 1462. As 
Reflecting upon the persons in the Trinity and their mutual love, the author of the commentary on Peter Lombard's Sentences wonders how their actions (love) may be something internal and remain inside the subject without going beyond it. ${ }^{37}$ The anonymous author wrote:

Perfect action or acting in a perfect manner requires that the agent (agens) acts upon a thing that is genuinely different from it. This is clear because the agent cannot define himself without acting through something, but that same thing cannot act of itself. ${ }^{38}$

The problem raised by the anonymous commentator (how can action occur and remain in the agent?) is solved by John of Głogów by extending the definition of action to internal acts:

We call an action internal when it is an act of the agent only and remains within the agent as perfection in its perfected subject (in suo perfectibili). The basis for this type of action is only the perfection of that in which it remains, as is the case of the theoretical thinking of a thinking subject. Conversely, we call an action external if it is not subordinated to the agent, which is perfected and provides its ultimate basis, but is performed by something else to which it is subordinated. ${ }^{39}$

master of arts and a bachelor of theology, he lectured for forty years. He commented on Aristotle (he wrote a long commentary on De anima and Metaphysics). Whereas Paul of Worczyn and Benedict Hesse are usually referred as via moderna followers, John is regarded as a via antiqua representative. See Knoll, A Pearl of Powerful Learning, op. cit., p. 343-345; for further references, see Jan z Głogowa, Quaestiones librorum de anima magistri Joanni Versoris per magistrum Joannem Glogoviensis universitatis stuii Cracoviensis maioris, Kraków 1514; Jan z Głogowa, Komentarz do Metafizyki, t. I-II, T. Tatarzyński (ed.), Warszawa, Akademia Teologii Katolickiej, 1984; KrauzeBłachowicz, K., «Ioannes Glogoviensis: the Modist Grammatarian on the Boundary between the Middle Ages and the Renaissance», Przeglad Tomistyczny, 9 (2003), pp. 123-138.

${ }^{37}$ Anonymi quaestiones in Sententias Petri Lombardi, q. 2, d. 2, in «Krakowski komentarz z XV wieku do Sentencji Piotra Lombarda. Cześć I. Wstęp historyczny i edycja tekstu księgi I i II», Z. Włodek (ed.), Studia Mediewistyczne, 7 (1966), p. 170: «Assumit primo, quod in Deo est summa caritas, secundo assumit quod perfecta et summa caritas non est amor privatus sed communis, tertio assumit, quod amor communis, qui non est privatus, non est solum amor in seipsum, sed etiam tendens in alterum [...]; Sed summam caritatem Deum non potest habere ad aliquid, quod Deus non est quia nihil citra ipsum est summe diligibile [...] summa et perfecta caritas requirit, ut qui diligit aliquem, velit illum ab alio summe [diligi] et perfecte sicut a se, si ergo Deus aliam personam quae etiam Deus est vult ab aliquo alio summo et perfecto amore diligi, sicut a se, non potest hoc esse nisi ibi tertia persona, quae etiam est Deus».

${ }^{38}$ Ibid.: «Suppositio secunda: perfecta actio vel perfectum agere requirit, quod agens agat [in] rem aliquam realiter a se distinctam. Illa patet, quia non meretur dici agens, nisi res aliqua agatur; sed idem non potest agere seipsum».

${ }^{39}$ John of Głogów, Komentarz do Metafizyki, t. II, R. Tatrzański (ed.), Warszawa, Akademia Teologii Katolickiej, 1984, p. 122: «Immanens dicitur operatio, quae est actus agentis tantum et manet in eo sicut perfectio in suo perfectibili. Talis enim operatio non eligitur propter aliud nisi propter perfectionem illius in quo manet, ut speculatio respectu speculantis. Sed ista operatio 
John not only considered internal acts to be a type of action, he also regarded them as actions that are more fundamental than external ones. As an example of an internal action, he mentioned theoretical thinking (speculatio). Paul of Worczyn did a similar thing: he considered the action of actual thinking, i.e., actual speculation, (speculatio actualis), to be action (operatio), albeit with a cognitive dimension. ${ }^{40}$ He claimed that, although

theoretical thinking does involve a certain respite from external motions; it is still a motion of the intellect itself because every action is motion. ${ }^{41}$

Therefore, if theoretical thinking is a motion of the intellect and every action is motion, then this type of thinking is a specific form of action.

In the Sixth Book of his commentary on Nicomachean Ethics, Paul elaborates Aristotle's definition of praxis. He agrees that this term concerns only actions taken as a result of human choice; ${ }^{42}$ however, he considers the problem of causes and principles of external actions, and he sees the source of external actions in the act of practical intellect. So, he offers the following interpretation:

a practical consideration can be related to appetite in a twofold manner: firstly, according to the nature of a principle that moves, prescribes, and orders, and in this way the consideration is practical but is not a praxis; secondly, according to nature [...], something is regulated and moved by the intellect, and so here it can be a praxis. ${ }^{43}$

What Paul is telling us here is that a practical consideration can be taken in two respects: active or passive. In the active respect, a practical consideration exists in the intellect and prescribes and orders something, such as the body that carries out the action, and in this respect it is not a praxis. The idea is straightforward enough. The practical thought that I ought to go jogging to keep myself healthy and fit, for instance, prescribes and orders my limbs to perform the bodily action of jogging. But the thought that prescribes and orders this action is not itself the action of jogging.

dicitur transiens, quae non ordinatur in agens sicut in perfectibile suum ultimatum, sed eligitur propter aliud in quod ordinatur».

${ }^{40}$ See ms BJ 720, f. 145va; Czartoryski, Wczesna recepcja Polityki, op. cit., 108.

${ }^{41}$ Paulus de Worczyn, Quaestiones super libris Ethicae Nicomacheae Aristotelis, op. cit., f. 194ra: «De alio, speculatio habet quidam quietem ab exterioribus motibus, nihilominus tamen speculari est quidam motus ipsius intellectus, prout quaelibet operatio dicitur motus, et sic dicitur III De anima: [sentire et intelligere dicitur quidam motus], prout motus dicitur perfectio perfecta».

${ }^{42}$ Paulus de Worczyn, Quaestiones super libris Ethicae Nicomacheae Aristotelis, op. cit., f. 145vb: «Respondetur secundum Eustratium est secundum electionem hominis operatio, id est, est operatio humana, quae est in hominis potestate, cui dominatur homo. Talis autem operatio est omnis operatio voluntatis elicita vel ab ea imperata».

${ }^{43}$ Ibid., f. 146rb: «[...] practica consideratio potest se dupliciter habere ad appetitum. Uno modo in ratione principii moventis dictantis et praeordinantis, et sic est practica et non est praxis. Alio modo in ratione [...] regulati et moti ab intellectu. Et sic ibi potest esse praxis». 
Things are different when we take practical consideration in a passive sense. So conceived, practical consideration exists in what is regulated and moved by the intellect, such as the limbs that I use to effect the action of jogging. Paul's view here is presumably that a bodily action somehow displays the practical thought that guides it, just as any effect, to some degree, displays its cause. This seems plausible enough: if you observe me jogging, you will likely infer that my bodily movement is guided by the practical consideration that I ought to jog.

Thus, Paul's interpretation of Aristotle's division between practica and praxis leads to the conclusion that an act of the practical intellect can also exist somehow in what is moved by the practical intellect, such as in the agent's body. Paul assumes that every external action has an internal cause (an act of the practical intellect) in such a way that the internal cause is manifested in the external action. This is not Paul's original thought. In his Treatise on Law, Aquinas discusses St. Paul's famous dictum «video aliam legem in membris meis»; in this context, Aquinas explains that a lex, which he takes to be a proposition of the practical intellect, may have a kind of participated existence in what is 'regulated' by it (for instance, in the agent's body):

cum lex sit regula quaedam et mensura, dicitur dupliciter esse in aliquo. Uno modo, sicut in mensurante et regulante. Et quia hoc est proprium rationis, ideo per hunc modum lex est in ratione sola. Alio modo, sicut in regulato et mensurato. Et sic lex est in omnibus quae inclinantur in aliquid ex aliqua lege, ita quod quaelibet inclinatio proveniens ex aliqua lege, potest dici lex, non essentialiter, sed quasi participative. (Sth I-II, q. 90, a. 1, ad 1).

Originating with Eustratius of Nicaea (a twelfth-century Byzantine bishop and author of a commentary on Nicomachean Ethics),${ }^{44}$ the definition of praxis is presented from a slightly different angle in the commentary of Gerald Odonis, which Paul used as a major source for his writing. ${ }^{45}$ Gerald writes:

We should therefore conclude that praxis is produced by the actions of man, the actions of man being something that man is defined by and can control. Any such action is praxis and any praxis is such an action. Thus, any such action [...] is universally prescribed by the will. ${ }^{46}$

\footnotetext{
${ }^{44}$ Ierodiakonou, K., «Eustratios of Nicaea», in H. Lagerlund (ed.), Encyclopedia of Medieval Philosophy. Philosophy Between 500 and 1500, Dordrecht/Heidelberg/London/New York, Springer, 2011, pp. 337-338.

${ }^{45}$ On Gerald Odonis see Porter, C., «Gerald Odonis' Commentary on the Ethics: A Discussion of the Manuscripts and General Survey», in W. Duba and Ch. Schabel (eds.), «Gerald Odonis, Doctor Morals and Franciscan Minister General», Vivarium, 47 (2009), pp. 241-294.

${ }^{46}$ Geraldus Odonis, Sententia et expositio cum q[uaesti]onibus Geraldi Odonis super libros Ethicorum Aristotelis cum textu eiusdem, Venetiis 1500, libr. VI, q. IV, f. 122: «Sed in oppositum est auctoritas Eustratii [...] in principio, qui sic describit praxem. Dicendum ergo cum eo quod praxis est secundum electionem hominis operatio, operatio humana quae est in hominis potestate cui
} 
Gerald's definition highlights the relationship between praxis and will, because praxis is an action (operatio) resulting from a choice willed by man. Similarly, Paul stresses that praxis is equivalent to actions governed by choice and originating in the will. ${ }^{47}$ However, Paul wrote that when we consider practical consideration as «regulati et moti ab intellectu», i.e., as moved and regulated by the intellect, then «ibi potest esse praxis». This sounds like a praxis is something that is «mota ab intellectu», in which case the intellect, not the will, seems to be a cause of action. How do we solve this inconsistency?

\section{The concept of soul and its powers}

Perhaps, the answer could be found in Paul's consideration on the soul and its powers. Paul is aware of the difference between the via antiqua and via moderna views; he opposed Aquinas's solutions and took the philosophical standpoint of John Buridan. After Buridan, he distinguishes between «principle powers» and «instrumental powers»; he then identifies the principle powers with the soul, stating that they are identical to the soul and perform their operations through various organs. He lists the vegetative, sensual and mental spheres as the principal powers.

Following the via moderna position, Paul believes that the difference between the principal powers and the soul is a difference in ratione, i.e., a conceptual difference which results from the various activities (powers) of the real substantial unity (soul). The ontological basis for his thesis on the real unity of the principal powers was provided by John Buridan's thesis on the substantial unity of the soul. The principal powers, which are identical to the soul itself, are not different from each other - they differ only in ratione. ${ }^{48}$

Apart from the principal powers, instrumental powers should also be distinguished: they are individual organs and their dispositions actually differ from each other. However, Paul did not consider them as belonging strictly to the soul. Instrumental powers are bodily organs and the dispositions of these organs, so - as Zdzisław Kuksewicz suggests -49 one should rather talk about intermediaries of the soul's actions, and not about the soul's powers. The organs belong to the body (which is separate from the soul and has its own substantial form).

definiatur homo. Omnis enim talis operatio est praxis et omnis praxis est talis operatio. Talis autem est omnis operatio voluntatis [...] universaliter imperata».

${ }^{47}$ Paulus de Worczyn, Quaestiones super libris Ethicae Nicomacheae Aristotelis, op. cit., f. 145vb: «Praxis [...] est operatio humana, quae est in hominis potestate, cui dominatur homo. Talis autem operatio est omnis operatio voluntatis elicita vel ab ea imperata»; See also Geraldus Odonis, Sententia et expositio, op. cit., libr. VI, q. IV, f. 122.

${ }^{48}$ Paulus de Worczyn, Quaestiones super tres libros De anima, op. cit., pp. 137-139.

${ }^{49}$ Kuksewicz, Z., Filozofia człowieka. Teoria duszy, Wrocław/Warszawa/Kraków/Gdańsk, Wydawnictwo IFiS PAN, 1975, p. 101. 
Still, a thesis which says that there is a difference in ratione between powers compels one to inquire about the basis of this distinction, which for Paul is various kinds of soul operations. This view of the soul expresses a strong emphasis on the essential and indissoluble unity of the soul in its various spheres of activity; this is supported by the understanding of the soul itself as a natural form of the body, and this was an important step on the way to understanding man as a completely natural being. ${ }^{50}$

Now, let's get back to Paul's question about the principle of action. As we have seen, Paul has certain requirements regarding the criteria that must be met by a principle in order to be a principle of action: for a principle to be the principium of motion, it must be motive, unmoved and internal. ${ }^{51}$ Thus, according to Paul of Worczyn, the principle that meets all these conditions is the soul. Precisely, the soul and its powers are both the first cause of the action because they effectively coincide, and only their rationes differ. Paul describes the soul as the first mover, the principle of motion, the cause of motion, or an element that causes all motion in $\operatorname{man}^{52}$. In other words, the soul has properties that enable it to impart motion. Paul also cites reflections from Book 8 of Aristotle's Physics, where the soul is compared to the first mover: the soul is able to move (mobilis) because it makes the body move, itself remaining immobile (immobilis). ${ }^{53}$

\section{Conclusion}

In conclusion, it is apt to observe that Cracow scholars understood action primarily as motion and change. This idea was investigated in terms of causes and principles, which are subject to two conditions: first, the principle of motion must be internal; second, it must be motive and unmoved. Thus, Paul of Worczyn suggests equating the principium of motion with the soul, both of which are identical. The rudiments of action ontology outlined in this article provide the foundation for Paul of Worczyn's anthropology and have further consequences for the theory of the soul.

In this text, I have attempted to describe Paul of Worczyn's theory of action. As I have shown above, Paul's understanding of action was deeply rooted in natural philosophy. Also, Paul shared some common views and intuitions about the category of action with other Cracow scholars (like Benedict Hesse, John of Głogów), which might suggest that there was general agreement in Cracow's academic environment as to

${ }^{50}$ Ibid., p. 102.

${ }^{51}$ Paulus de Worczyn, Quaestiones super tres libros De anima, op. cit., p. 44.

${ }^{52}$ Paulus de Worczyn, Quaestiones super tres libros De anima, op. cit., pp. 43-44: «[Scientia] de anima, quae pertinet ad mobile ut principium vel causa motus, quia causat motum in homine».

${ }^{53}$ Paulus de Worczyn, Quaestiones super tres libros De anima, op. cit., p. 44: «Tunc tamen physicae considerationis secundum quamdam rationem accidentalem ut 8 Physicorum consideratur de primo motore non quoad quidditatem de anima. Aliter dicitur, quod anima humana etiam aliqualiter est mobilis, quia ad motum corporis, et ergo negandum est, quod anima humana est immobilis». 
what action really is. The theory of action, which can be found in the VI, VII and X books of Paul's commentary on Nicomachean Ethics, is central in his work and serves as an important point of reference when attempting to understand the deep roots of educational and philosophical programs in medieval Cracow.

Magdalena Plotka magdalenaplotka@gmail.com

Fecha de recepción: 30/08/2019

Fecha de aceptación: 20/11/2020 